\title{
Ni-Co Bimetallic Catalyst Synthesis by Co-impregnation Method for Hydrogen Rich Gas Production from Olive Pomace
}

\author{
Vildan Aker and Nezihe Ayas
}

\begin{abstract}
Hydrogen is defined as an ideal energy carrier among sustainable, clean and renewable energy sources, so it is important to produce hydrogen and to develop the sustainable hydrogen economy. Catalyst plays a vital role in the production of hydrogen at low cost and high efficiency. Selection of support and active material, catalyst preparation methods considerably affect the activity of the catalysts. In this work, Ni-Co bimetallic based catalysts were synthesized by the co-impregnation

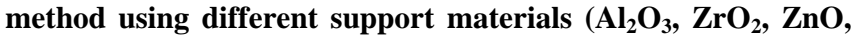
$\mathrm{Al}_{2} \mathrm{O}_{3}-\mathrm{ZrO}_{2}$ ) in order to obtain the highest hydrogen-rich gas from biomass. Ni-Co bimetallic catalysts were synthesized and characterized by XRD, XRF, TGA, SEM and FT-IR techniques. The activities of $\mathrm{Ni}-\mathrm{Co} / \mathrm{Al}_{2} \mathrm{O}_{3}, \mathrm{Ni}-\mathrm{Co} / \mathrm{Al}_{2} \mathrm{O}_{3}-\mathrm{ZrO}_{2}$ catalyst were studied in gasification of olive pomace. It was found that the $\mathrm{H}_{2}$ yield of the $\mathrm{Ni}-\mathrm{Co} / \mathrm{Al}_{2} \mathrm{O}_{3}\left(10.76 \mathrm{~mole} \mathrm{H}_{2} / \mathrm{kg}\right.$ Olive pomace) was higher than $\mathrm{Ni}-\mathrm{Co} / \mathrm{Al}_{2} \mathrm{O}_{3}-\mathrm{ZrO}_{2}$ (5.37 mole $\mathrm{H}_{2} / \mathrm{kg}$ Olive pomace).
\end{abstract}

Index Terms-Catalyst, co-impregnation, hydrogen, olive pomace gasification.

\section{INTRODUCTION}

Research on alternative energy has increased considerably since fossil fuel reserves will soon be exhausted, and cause environmental pollution and health problems [1], [2]. Renewable energy is the most important alternative energy source since it is clean, sustainable and more stable than fossil fuels in terms of price [3]. Hydrogen is regarded as a clean energy carrier [3], [4]. Biomass, one of the hydrogen production sources, draws attention as a supply of $\mathrm{CO}_{2}$ as neutral energy because $\mathrm{CO}_{2}$ generated in the conversion process is consumed by biomass growth [3]. Catalysts play a crucial role in hydrogen production [5]. Active catalysts should maximize hydrogen selectivity, minimize coke formation, and prevent CO production [6]. Non-noble metal catalysts such as $\mathrm{Ni}$ - and $\mathrm{Co}$ - metallic based are often preferred in catalyst production studies. Although nickel is highly preferred by the reason of low cost, good activity, selectivity, ability in cleavage $\mathrm{C}-\mathrm{C}, \mathrm{C}-\mathrm{O}$ and $\mathrm{C}-\mathrm{H}$ bonds, some problems such as coke formation and metal sintering are encountered [3], [7]. Bimetallic catalysts have been developed in order to achieve higher catalyst performance

Manuscript received February 5, 2018; revised January 10, 2019. This study was supported by Eskişehir Technical University Scientific Research Projects Commission under the grant no: 1706F396.

Vildan Aker is with Department of Chemical Engineering, Faculty of Engineering, Eskişehir Technical University, 2 Eylul Campus, Eskisehir, 26555, Turkey (e- mail: aker.vildan@gmail.com).

Nezihe Ayas is with Department of Chemical Engineering, Faculty of Engineering, Eskişehir Technical University, 2 Eylul Campus, Eskisehir, 26470, Turkey (e-mail: neziheayas@gmail.com). and improve the electronic properties of the metal surface [8] $\mathrm{Ni}$-Co bimetallic catalyst increases the water-gas shift reaction which plays an important role in hydrogen yield [7]. $\mathrm{Ni}$-Co with high dispersion of the active phase, strong metal-support fundamental interaction and high coke resistance is developed [9]. Several oxides have been investigated as a support material to provide optimum metallic distribution, the thermal stability of the metal phase and to participate in the catalytic process [5].

Mediterranean countries such as Turkey have mainly olive oil industry. Olive oil mill waste produced in large quantities in a short time in the Mediterranean regions represents an important environmental problem. Turkey annually produces approximately $700 \mathrm{kt}$ and $120 \mathrm{kt}$ olive pomace. A large portion of olive oil wastes contains valuable resources such as organic matter and recyclable nutrients. The estimated amounts of wastes derived from the olive oil industry in Europe are 6.8 million tons/year, which is about $18 \mathrm{MJ} / \mathrm{kg}$ promising energy content [10]

Although there are studies about olive pomace in the literature, few studies are on the olive pomace gasification.

Puig-Gamero et al. compared the gasification of olive pomace, coal, petcoke and binary or triple mixtures. The maximum $\mathrm{H}_{2} / \mathrm{CO}$ ratio of pomace-petcoke mixture, coal and olive pomace was determined as 0.0250, 0.0145, 0.00611, respectively [11].

Borello et al. have investigated thermo-economical analysis of heat and energy of synthetic gas produced from olive pomace by gasification. The low heating value (LHV) (on dry material basis) of the synthesis gas was found to be $5.4 \mathrm{MJ} / \mathrm{kg}$ [12].

Sert et al. gasified olive pomace by hydrothermal gasification in the presence of trona, $\mathrm{K}_{2} \mathrm{CO}_{3}$, and $\mathrm{KOH}$ using batch autoclave reactor. The maximum $\mathrm{H}_{2}$ yield was obtained as $16.80 \mathrm{~mol} / \mathrm{kg}$ biomass at $600^{\circ} \mathrm{C}$ in the presence of $\mathrm{KOH}$ catalyst [10].

Within this work, the influence of different support materials $\left(\mathrm{Al}_{2} \mathrm{O}_{3}, \mathrm{ZrO}_{2}, \mathrm{ZnO}, \mathrm{Al}_{2} \mathrm{O}_{3}-\mathrm{ZrO}_{2}\right)$ of the catalyst on the formation of crystal morphology and on the distribution of catalytic active species was investigated. Ni-Co based catalysts were synthesized using co-impregnation method. Catalysts were characterized by XRD (X-ray diffraction measurements), XRF (X-ray fluorescence spectroscopy), SEM (Scanning Electron Microscope) and TGA (Thermo Gravimetric Analyses) techniques. The activity of the catalyst was determined by performing gasification of olive pomace. 


\section{EXPERIMENTAL}

\section{A. Materials}

Nickel nitrate hexahydrate $\left[\mathrm{Ni}\left(\mathrm{NO}_{3}\right)_{2} \cdot 6 \mathrm{H}_{2} \mathrm{O}\right]$ and Cobalt (II) nitrate hexahydrate $\left[\mathrm{Co}\left(\mathrm{NO}_{3}\right)_{2} \cdot 6 \mathrm{H}_{2} \mathrm{O}\right]$ were purchased from Sigma-Aldrich which were used as nickel and cobalt active metal phase precursors, respectively.

Aluminum oxide $\left[\mathrm{Al}_{2} \mathrm{O}_{3}\right]$, zirconium (IV) oxynitrate hydrate $\left[\mathrm{ZrO}\left(\mathrm{NO}_{3}\right)_{2} \cdot \mathrm{xH}_{2} \mathrm{O}\right.$ ], zinc oxide [ZnO], zirconium (IV) oxide $\left[\mathrm{ZrO}_{2}\right]$ were purchased from Sigma-Aldrich. All the chemicals were used without any pre-treatment. Olive pomace was supplied from olive oil factory in Turkey and dried before gasification.

\section{B. Catalyst Preparation}

Ni-Co bimetallic catalyst was synthesized by the co-impregnation method using $\mathrm{Al}_{2} \mathrm{O}_{3}, \mathrm{ZrO}_{2}, \mathrm{ZnO}$, $\mathrm{Al}_{2} \mathrm{O}_{3}-\mathrm{ZrO}_{2}\left(10 \% \mathrm{ZrO}_{2}\right.$ (wt/wt) as support materials. The amount of active metal loaded was kept constant as Ni $10 \%$ (wt/wt) and Co 5\% (wt/wt).

Synthesizing $\mathrm{Al}_{2} \mathrm{O}_{3}-\mathrm{ZrO}_{2} \quad\left(10 \% \quad \mathrm{ZrO}_{2}\right.$ (wt/wt) support material: The required amounts of precursors were dissolved in distillated water with 1:5 catalysts:water ratio (wt/wt), the solution was stirred in a magnetic stirrer water bath at $70^{\circ} \mathrm{C}$ for 3 hours. After aging the mixture at room temperature for a day, it was dried at $105^{\circ} \mathrm{C}$ overnight and then calcined at $550^{\circ} \mathrm{C}\left(2^{\circ} \mathrm{C} / \mathrm{min}\right)$ for 3 hours under an air flow.

Loading active metals over the support: The appropriate amount of nickel and cobalt nitrates were dissolved in distilled water with a 1:5 catalyst: water ratio (wt/wt). The nitrate aqueous solutions were added over the support material and placed in a water bath at $70^{\circ} \mathrm{C}$ and stirred for 3 hours and then the mixture was aged at room temperature for a day then dried at $105^{\circ} \mathrm{C}$ overnight and calcined at $550^{\circ} \mathrm{C}$ $\left(2^{\circ} \mathrm{C} / \mathrm{min}\right)$ for 3 hours under an air flow.

\section{Catalyst Characterization}

TGA (Thermo Gravimetric Analyses) was carried out using Netzsch STA 409 PG model thermal analysis system at $900^{\circ} \mathrm{C}$ in $\mathrm{N}_{2}$ atmosphere at a heating rate of $10^{\circ} \mathrm{C} / \mathrm{min}$.

XRD (X-Ray Diffraction) patterns were performed with a Rigaku Rint 2200 X-ray diffractometer employing the graphite filtered $\mathrm{Cu}-\mathrm{K} \alpha$ radiation over $2 \theta=15-85^{\circ}$ and scanning rate $4 \%$ s.

XRF (X-ray fluorescence spectroscopy) was determined by Rigaku ZSX model XRF instrument to determine the mass composition of the catalysts.

SEM (Scanning Electron Microscope) was conducted on Zeiss EVO 50 VP model scanning electron microscope at 20 $\mathrm{kV}$.

FT-IR analyses were performed at room temperature on a Thermo Scientific Nicolet IS10. Spectra are recorded in the range $400-4000 \mathrm{~cm}^{-1}$ with an accumulation of 64 scans and a resolution of $4 \mathrm{~cm}^{-1}$.

\section{Catalytic Activity Test}

The catalytic tests were performed using an updraft tubular reactor $(\Phi 1 \times 90 \mathrm{~cm})$. The reactor was heated with an electrical power supply which was capable of increasing the temperature from ambient temperature to maximum $850^{\circ} \mathrm{C}$ in $60 \mathrm{~s}$. The schematic diagram is shown in Figure 1.
The biomass and catalyst mixture were loaded into the reactor then, the reactor was placed in a ceramic insulator. The power supply was turned on and the air was introduced from the bottom of the reactor.

During the gasification process, the gaseous product was continuously collected in a gas collecting bag.

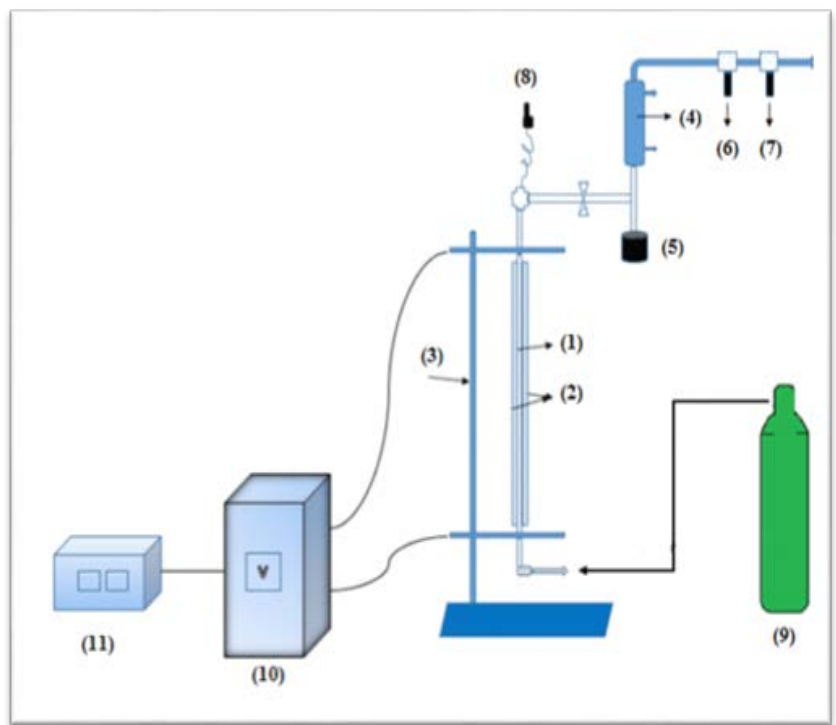

Fig. 1. The schematic diagram of experimental apparatus; 1-tubular reactor 2-isolation cylinder, 3-stand, 4-liquid-gas separator, 5-liquid product chamber, 6-filter for particles, 7-filter for moisture, 8-thermocouple, 9-air supplier, 10-power supplier, 11-controller.

Gasification reactions were carried out at $650^{\circ} \mathrm{C}$ for 20 minutes using $20 \%$ wt catalyst/wt biomass. Prior to the activity tests, the catalysts were reduced at $800^{\circ} \mathrm{C}$ using $20 \%$ $\mathrm{H}_{2}$ and $\mathrm{N}_{2}$ mixture with the flow rate of $300 \mathrm{~mL} / \mathrm{min}$ for 30 $\min$.

The gas product was analyzed SRA Technologies Micro Gas Chromatograph ( $\mu-\mathrm{GC}$ ) (T-3000 series) equipped with

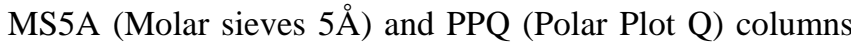
coupled to thermal conductivity detector (TCD). While the standard gas mixture was used for $\mu$-GC calibration, helium and argon were used as a carrier.

\section{RESUlTS AND DisCUSSION}

\section{A. Catalyst Characterization}

TGA analyses of catalysts are given in Figure 2.

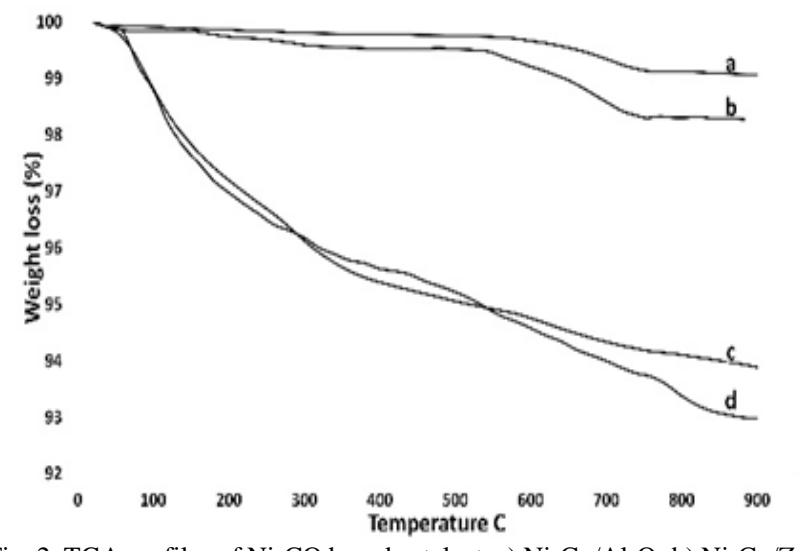

Fig. 2. TGA profiles of Ni-CO based catalyst. a) Ni-Co/ $/ \mathrm{Al}_{2} \mathrm{O}_{3}$ b) $\mathrm{Ni}-\mathrm{Co} / \mathrm{ZrO}_{2}$ c) $\mathrm{Ni}-\mathrm{Co} / \mathrm{ZnO}$ d) $\mathrm{Ni}-\mathrm{Co} / \mathrm{Al}_{2} \mathrm{O}_{3}-\mathrm{ZrO}_{2}$. 
As it is displayed in Figure 2, overall weight loss for the catalyst is about 2-7 wt. \%. The mass changes up to $200^{\circ} \mathrm{C}$ are associated with the removal of adsorbed water and volatile material present in the catalyst. This water is caused by surface water and hydrates in metal nitrates. At about $300-400^{\circ} \mathrm{C}$, the weight loss was attributed to the conversion of metal hydroxides to metal oxides.

The mass loss of the catalyst seems to continue to about $550^{\circ} \mathrm{C}$, and it is negligible after $550^{\circ} \mathrm{C}$. It is seen that the calcination temperature of the catalysts of $550^{\circ} \mathrm{C}$ overlaps with the TGA graph.

\section{B. XRD Analysis}

XRD patterns of bimetallic catalysts calcined at $550^{\circ} \mathrm{C}$ are shown in Figure 3.

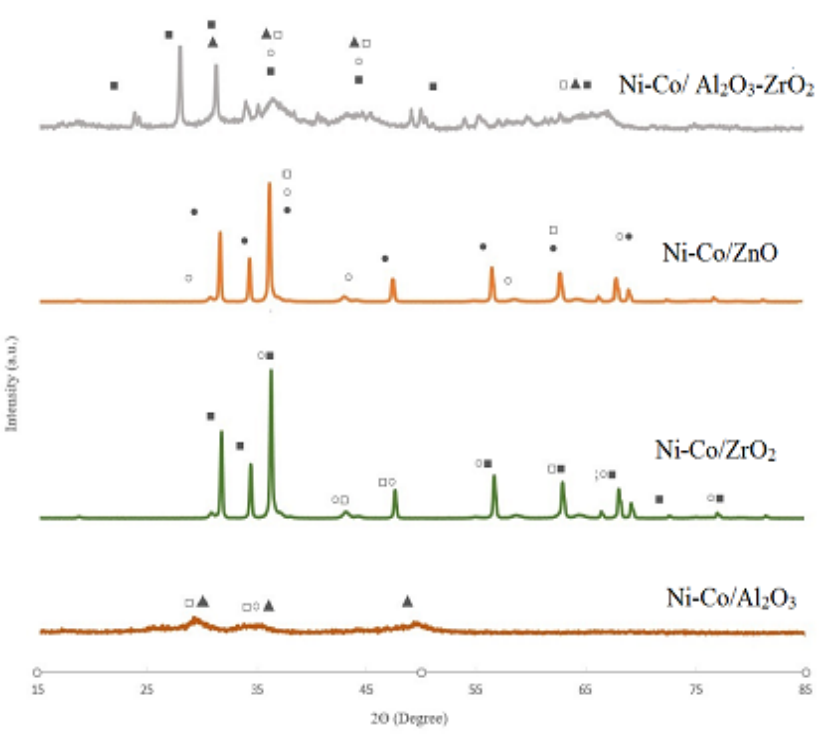

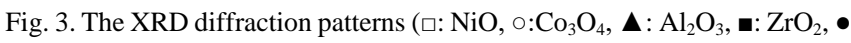
$\mathrm{ZnO})$.

The XRD diffraction patterns (Figure 3) show that the catalysts have $\mathrm{NiO}$ characteristic peaks at $2 \theta=37.3^{\circ}, 43.2^{\circ}$, $62.9^{\circ}$ and $79.4^{\circ}, \mathrm{Co}_{3} \mathrm{O}_{4}$ characteristic peaks at $2 \theta=44.2^{\circ}$, $51.4^{\circ}, 75.7^{\circ}$, the characteristic peaks of $\gamma-\mathrm{Al}_{2} \mathrm{O}_{3}$ at $2 \theta=37.3^{\circ}$, $45.7^{\circ}$ and $60.8^{\circ}, \mathrm{ZrO}_{2}$ at $2 \theta=30.2^{\circ}$ and $50.3^{\circ}$.

The molecular structure of $\mathrm{Ni}-\mathrm{Co} / \mathrm{ZnO}$ and $\mathrm{Ni}-\mathrm{Co} / \mathrm{ZrO}_{2}$ catalysts are highly crystalline. In contrast, $\mathrm{Ni}-\mathrm{Co} / \mathrm{Al}_{2} \mathrm{O}_{3}$ and $\mathrm{Ni}-\mathrm{Co} / \mathrm{Al}_{2} \mathrm{O}_{3}-\mathrm{ZrO}_{2}$ catalysts are amorphous. The decrease of the intensities of the $\mathrm{NiO}, \mathrm{CoO}$ and $\mathrm{Al}_{2} \mathrm{O}_{3}$ peaks is observed by adding $\mathrm{ZrO}_{2}$.

Partial overlap is observed in the diffraction peaks of $\mathrm{Ni}$ and Co due to similar morphology. For this reason, it is difficult to discriminate between $\mathrm{Co}$ and Ni species.

\section{XRF Analysis}

The XRF results of Ni-Co based catalysts are given according to different support materials in Table 1 . Ni and Co (wt./wt.) loading rates were calculated over $\mathrm{Ni}$ and $\mathrm{Co}$, and XRF results are given in $\mathrm{NiO}$ and $\mathrm{Co}_{2} \mathrm{O}_{3}$.

Table 1 clearly lists that $\mathrm{Ni}$ and $\mathrm{Co}$ contents are close to the desired values. As calculations are based on metallic Ni and Co, XRF results are higher than the desired value since they are in oxide form. Due to the impurities of the precursors used in the catalysts, there have been negligible deviations in the amount of support material loading.
The results display clearly that crystallite size of metal depends on support material of catalyst. The smallest average crystallite size calculated from XRD patterns was determined to be $0.45 \mathrm{~nm}$ with $\mathrm{Ni}-\mathrm{Co} / \mathrm{Al}_{2} \mathrm{O}_{3}$ catalyst.

TABLE I: XRF RESULTS OF N-CO CATALYSTS

\begin{tabular}{|c|c|c|c|c|c|c|}
\hline \multirow{2}{*}{ Catalysts } & \multicolumn{5}{|c|}{ Components (wt./wt.) } & \multirow{2}{*}{$\begin{array}{c}\text { Crystall } \\
\text { ite size } \\
(\mathbf{n m})^{a} \\
\end{array}$} \\
\hline & $\mathrm{NiO}$ & $\mathrm{Co}_{2} \mathrm{O}_{3}$ & $\mathrm{Al}_{2} \mathrm{O}_{3}$ & $\mathrm{ZnO}$ & $\mathrm{ZrO}_{2}$ & \\
\hline $\begin{array}{c}\mathrm{Ni}-\mathrm{Co} / \mathrm{Al}_{2} \mathrm{O}_{3} \\
(10 / 5 / 85)\end{array}$ & $\begin{array}{c}13.1 \\
5\end{array}$ & 6.52 & 78.79 & - & - & 0.45 \\
\hline $\begin{array}{c}\mathrm{Ni}-\mathrm{Co} / \mathrm{ZnO} \\
(\mathbf{1 0} / 5 / 85)\end{array}$ & $\begin{array}{c}13.1 \\
3\end{array}$ & 7.00 & - & 79.18 & - & 8.06 \\
\hline $\begin{array}{c}\mathrm{Ni}-\mathrm{Co} / \mathrm{ZrO}_{2} \\
(\mathbf{1 0} / 5 / 85)\end{array}$ & $\begin{array}{c}13.8 \\
0\end{array}$ & 7.51 & - & - & 76.29 & 7.18 \\
\hline $\begin{array}{c}\mathrm{Ni}-\mathrm{Co} / \\
\mathrm{Al}_{2} \mathrm{O}_{3}-\mathrm{ZrO}_{2} \\
(\mathbf{1 0} / 5 / 85)\end{array}$ & $\begin{array}{c}10.4 \\
8\end{array}$ & 5.91 & 73.04 & - & 6.17 & 7.25 \\
\hline
\end{tabular}

a Determined by XRD- calculated by the Scherrer formula.

\section{SEM Images}

The result of the SEM analysis (Fig. 4) clearly indicates the surface of all catalysts appears to be porous. Some aggregates formed by very small particles are also present.

It can be seen that $\mathrm{Ni}-\mathrm{Co} / \mathrm{Al}_{2} \mathrm{O}_{3}$ is coarse, porous, and spherical compared to other catalysts, hence it should have a large BET surface area. Irregular shaped large particles with variable sizes and forms are observed in $\mathrm{Ni}-\mathrm{Co} / \mathrm{ZnO}$. The $\mathrm{Ni}-\mathrm{Co} / \mathrm{Al}_{2} \mathrm{O}_{3}-\mathrm{ZrO}_{2}$ catalyst exhibits surface morphology similar to $\mathrm{Ni}-\mathrm{Co} / \mathrm{ZrO}_{2}$ catalyst by addition of $\mathrm{ZrO}_{2}$.

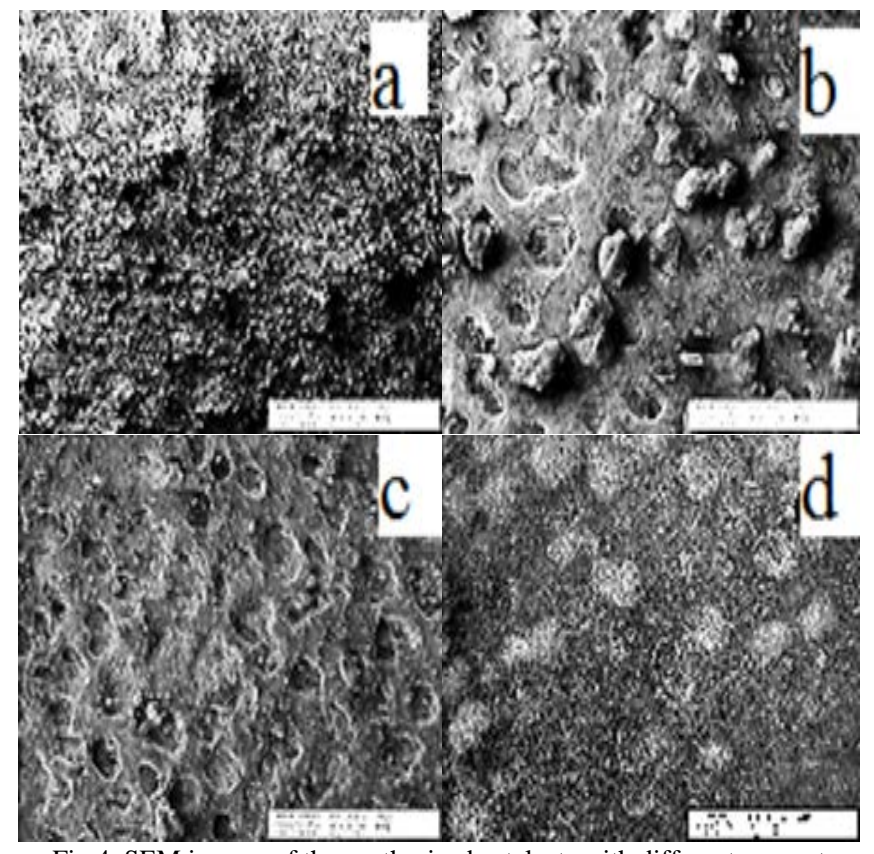

Fig.4. SEM images of the synthesized catalysts with different support materials. a) $\mathrm{Ni}-\mathrm{Co} / \mathrm{Al}_{2} \mathrm{O}_{3}$ b) $\mathrm{Ni}-\mathrm{Co} / \mathrm{ZnO}$ c) $\mathrm{Ni}-\mathrm{Co} / \mathrm{ZrO}_{2}$ d) $\mathrm{Ni}-\mathrm{Co} / \mathrm{Al}_{2} \mathrm{O}_{3}-\mathrm{ZrO}_{2}$.

\section{E. FT-IR Analysis}

FT-IR results of fresh calcined catalyst are demonstrated in Figure 5. 


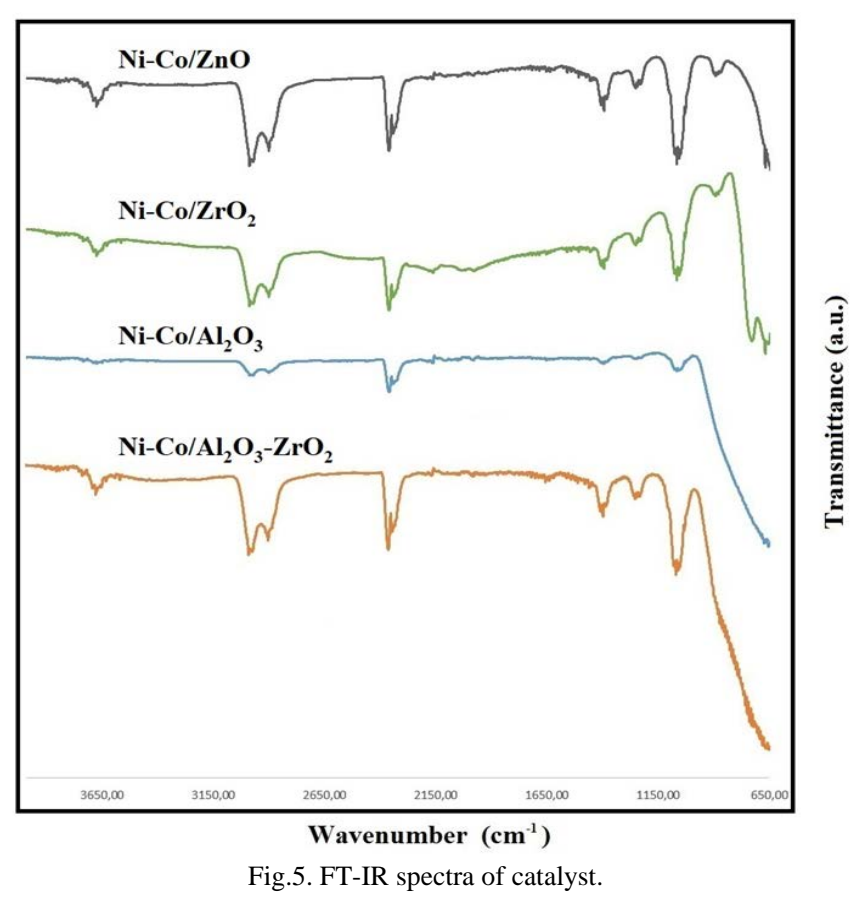

Figure 5 presents, the FT-IR peaks observed in the lower than $1000 \mathrm{~cm}^{-1}$ are present due to metal oxides $\left(\mathrm{NiO}, \mathrm{Co}_{3} \mathrm{O}_{4}\right)$ arising from interatomic vibrations. The low-level definition of this band is due to the amorphous state. This confirms the results obtained from the XRD characterization (Fig.3) of the high metal distribution. Vibrational modes in the range 1100 $\mathrm{cm}^{-1}$ correspond to the adsorbed water and $\mathrm{M}-\mathrm{OH}(\mathrm{M}=\mathrm{Ni}$, $\mathrm{Co}, \mathrm{Al}, \mathrm{Zr}$ ).

The peaks around 1000-1500 and 3000-4000 $\mathrm{cm}^{-1}$ are present due to $\mathrm{Al}-\mathrm{OH}$ (hydroxyl groups) and $\mathrm{Zr}-\mathrm{OH}$. Surface $\mathrm{OH}$ species have positive effects such as removal of carbon from the surface.

The peak which indicated about $2300 \mathrm{~cm}^{-1}$ is caused by the asymmetric stretching frequency of $\mathrm{CO}_{2}$ which is resulted in the aerial $\mathrm{CO}_{2}$.

The peaks around $2857-2920 \mathrm{~cm}^{-1}$ are assigned to stretching vibration for structural C-H bands.

\section{F. Activity Tests}

The activity of catalyst was determined in the gasification of olive pomace (Figure 6).

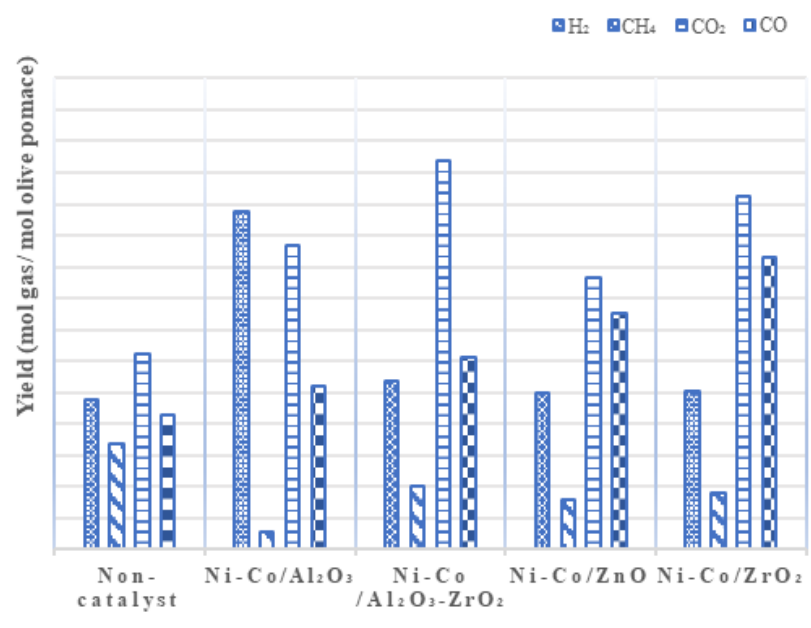

Fig. 6. Effect of support on gaseous product composition $\left(650^{\circ} \mathrm{C}, 20 \mathrm{~min}\right.$ reaction time and $20 \mathrm{wt}$ \% catalyst ratio).
Figure 6 shows the yield of the main component of the gas product which are $\mathrm{H}_{2}, \mathrm{CH}_{4}, \mathrm{CO}$ and $\mathrm{CO}_{2}$. The $\mathrm{H}_{2}$ yield followed the order $\mathrm{Ni}-\mathrm{Co} / \mathrm{Al}_{2} \mathrm{O}_{3}>\mathrm{Ni}-\mathrm{Co} / \mathrm{Al}_{2} \mathrm{O}_{3}-\mathrm{ZrO}_{2}>$ $\mathrm{Ni}-\mathrm{Co} / \mathrm{ZrO}_{2}>\mathrm{Ni}-\mathrm{Co} / \mathrm{ZnO}$.

While $\mathrm{H}_{2}$ yield was $4.78 \mathrm{~mol} / \mathrm{kg}$ olive pomace without the catalyst, it reached maximum value with $10.76 \mathrm{~mol} \mathrm{H}_{2} / \mathrm{kg}$ olive pomace in the presence of $\mathrm{Ni}-\mathrm{Co} / \mathrm{Al}_{2} \mathrm{O}_{3}$, which could be attributed its high metal dispersion (Fig. 3, Fig.4). Further, minimum $\mathrm{H}_{2}$ yield was obtained as $5.02 \mathrm{~mol} \mathrm{H}_{2} / \mathrm{kg}$ olive pomace with $\mathrm{Ni}-\mathrm{Co} / \mathrm{ZnO}$.

As the maximum of methane yield was obtained as 3.37 mol CH$/ 4 / \mathrm{kg}$ olive pomace in the absence of the catalyst and minimum methane yield was obtained as $0.54 \mathrm{~mol} \mathrm{CH}_{4} / \mathrm{kg}$ olive pomace using $\mathrm{Ni}-\mathrm{Co} / \mathrm{Al}_{2} \mathrm{O}_{3}$.

Besides, Ni-Co / ZnO catalyst produced at least $\mathrm{CO}_{2}(8,63$ mol CO $2 / \mathrm{kg}$ olive pomace) as a by-product compared to other catalysts, while maximum $\mathrm{CO}_{2}$ yield was obtained as 12.39 mol $\mathrm{CO}_{2} / \mathrm{kg}$ olive pomace in the presence of $\mathrm{Ni}-\mathrm{Co} / \mathrm{Al}_{2} \mathrm{O}_{3}-\mathrm{ZrO}_{2}$.

CO yield ranges between 8.63 and $12.39 \mathrm{~mol} \mathrm{CO} / \mathrm{kg}$ olive pomace at catalytic activity studies. The minimum CO yield in the product gas composition was obtained as $6.23 \mathrm{~mol}$ $\mathrm{CO} / \mathrm{kg}$ olive pomace without the catalyst.

The higher production of $\mathrm{H}_{2}$ and $\mathrm{CO}_{2}$, and the much lower production of $\mathrm{CH}_{4}$ and $\mathrm{CO}$ showed that the contribution of the methane steam reforming and the water gas shift reaction were much favored.

As a result, $\mathrm{Ni}-\mathrm{Co} / \mathrm{Al}_{2} \mathrm{O}_{3}$ catalysts were found to be favorable catalysts for gasification of olive pomace.

\section{CONCLUSION}

As a conclusion; $\mathrm{Ni}-\mathrm{Co} / \mathrm{Al}_{2} \mathrm{O}_{3}, \mathrm{Ni}-\mathrm{Co} / \mathrm{ZrO}_{2}, \mathrm{Ni}-\mathrm{Co} / \mathrm{ZnO}$, $\mathrm{Ni}-\mathrm{Co} / \mathrm{Al}_{2} \mathrm{O}_{3}-\mathrm{ZrO}_{2}$ catalysts were synthesized and characterized by XRD, XRF, TGA, SEM and FT-IR analyzes. Activity studies were carried out by performing gasification of olive pomace.

The highest hydrogen yield was found as $10.76 \mathrm{~mol} / \mathrm{kg}$ olive pomace at the gasification conditions of $650^{\circ} \mathrm{C}, 20 \mathrm{~min}$ reaction time and 20 wt.\% catalyst ratio in presence of $\mathrm{Ni}-\mathrm{Co} / \mathrm{Al}_{2} \mathrm{O}_{3}$. When the yield was compared with literature, Sert et al. obtained higher hydrogen yield $(16.80 \mathrm{~mol} / \mathrm{kg}$ biomass at $600^{\circ} \mathrm{C}$ ). The reason for the difference is due to the use of hydro-thermal gasification method.

\section{ACKNOWLEDGMENT}

This study was supported by Eskişehir Technical University Scientific Research Projects Commission under the grant no: $1706 \mathrm{~F} 396$.

\section{REFERENCES}

[1] H. Ma, L. Zeng, H. Tian, D. Li, X. Wang, X. Li, and J. Gong, “Efficient hydrogen production from ethanol steam reforming over La-modified ordered mesoporous Ni-based catalysts,” Applied Catalysis B: Environmental, vol. 181, pp. 321-331, 2016.

[2] C. Pirez, W. Fang, M. Capron, S. Paul, H. Jobic, F. Dumeignil, and L. Jalowiecki-Duhamel, "Steam reforming, partial oxidation and oxidative steam reforming for hydrogen production from ethanol over cerium nickel based oxyhydride catalyst," Applied Catalysis A: General, vol. 518, pp. 78-86, 2016.

[3] T. Mondal, K. K. Pant, and A. K. Dalai, "Catalytic oxidative steam reforming of bio-ethanol for hydrogen production over Rh promoted 
$\mathrm{Ni} / \mathrm{CeO}_{2}-\mathrm{ZrO}_{2}$ catalyst," International Journal of Hydrogen Energy, vol. 40, no. 6, pp. 2529-2544, 2015.

[4] R. González-Gil, C. Herrera, M. A. Larrubia, F. Mariño, M. Laborde, and L. J. Alemany, "Hydrogen production by ethanol steam reforming over multimetallic $\mathrm{RhCeNi} / \mathrm{Al}_{2} \mathrm{O}_{3}$ structured catalyst Pilot-scale study," International Journal of Hydrogen Energy, vol. 41, no. 38, pp. 16786-16796, 2016.

[5] T. Hou, S. Zhang, Y. Chen, D. Wang, and W. Cai, "Hydrogen production from ethanol reforming: Catalysts and reaction mechanism," Renewable and Sustainable Energy Reviews, vol. 44, pp. 132-148, 2015

[6] M. Ni, D. Y. Leung and M. K. Leung, "A review on reforming bio-ethanol for hydrogen production", International Journal of Hydrogen Energy, vol. 32, pp. 3238-3247, 2007.

[7] X. Zhao, and G. Lu, "Modulating and controlling active species dispersion over $\mathrm{Ni}-\mathrm{Co}$ bimetallic catalysts for enhancement of hydrogen production of ethanol steam reforming," International Journal of Hydrogen Energy, vol. 41, pp. 3349-3362, 2016.

[8] B. Cifuentes, M. F. Valero, J. A. Conesa, and M. Cobo, "Hydrogen production by steam reforming of ethanol on Rh-Pt catalysts: Influence of $\mathrm{CeO}_{2}, \mathrm{ZrO}_{2}$, and $\mathrm{La}_{2} \mathrm{O}_{3}$ as supports," Catalysts, vol. 5, pp. 1872-1896, 2015.

[9] S. Mahboob, M. Haghighi, and F. Rahmani, "Sonochemically preparation and characterization of bimetallic Ni-Co/ $/ \mathrm{Al}_{2} \mathrm{O}_{3} \cdot \mathrm{ZrO}_{2}$ nanocatalyst: Effects of ultrasound irradiation time and power on catalytic properties and activity in dry reforming of $\mathrm{CH}_{4}$," Ultrasonics Sonochemistry, vol. 38, pp. 38-49, 2017.

[10] M. Sert, D. S. Gökkaya, N. Cengiz, L. Ballice, M. Yüksel, and M. Sağlam, "Hydrogen production from olive-pomace by catalytic hydrothermal gasification," Journal of the Taiwan Institute of Chemical Engineers, vol. 83, pp. 90-98, 2017.

[11] M. Puig-Gamero, J. Lara-Díaz, J. L. Valverde, P. Sánchez, and L. Sanchez-Silva, "Synergestic effect in the steam co-gasification of olive pomace, coal and petcoke: Thermogravimetric-mass spectrometric analysis," Energy Conversion and Management, vol. 159, pp. 140-150, 2018.

[12] D. Borello, B. De Caprariis, P. De Filippis, A. Di Carlo, A. Marchegiani, A. M. Pantaleo, and P. Venturini, "Thermo-economic assessment of a olive pomace gasifier for cogeneration applications," Energy Procedia, vol. 75, pp. 252-258, 2015.

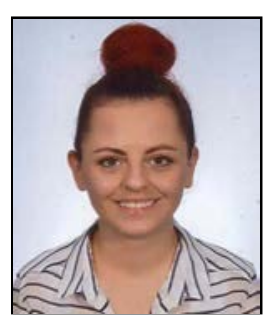

Vildan Aker was born in Turkey. She graduated from Department of Chemical Engineering, Anadolu University Eskişehir. She currently does master degree at the same department.

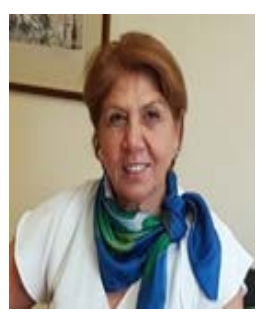

Nezihe Ayas is a doctor of chemical engineering, professor at Department of Chemical Engineering, Faculty of Engineering, Anadolu University. She is head of Unit Operations and Thermodynamics Division, supervisor of biofuel laboratory at Chemical Engineering Department. She has experience in research of biofuel, gasification of biomass, hydrogen production from biomass, catalyst synthesis for biofuel and hydrogen production. She is an author and a co-author of several publications related to renewable energy such as biodiesel, hydrogen from biomass in supercritical water gasification, hydrogen from biomass by gasification and steam reforming, catalyst synthesis for hydrogen production. She teaches students in the fields of: thermodynamics, mass transfer, hydrogen from biomass and others. 
Modern Machinery and Manufacturing

Engineering 
